\title{
5
}

\section{Trespassing in Cultural History: The Heroines of Romola and Orlando}

Eliot and Woolf claim the significance of every element of ordinary life in a history less exclusive than the tradition of masterpieces or the pantheon of great men. In practice, however, their own narratives' claim to significance is based on high standards of exclusion; texts displaying such cultivated intelligence and discriminating artistry escape the brown pond of the commonplace. The prosaic traditionally calls out for the intervention of miraculous beings, what $\mathrm{D}$. H. Lawrence in his "Study of Thomas Hardy" calls aristocrats: "The glory of mankind is not in a host of secure . . . citizens, but in the few more fine, clear lives, . . . individuals, distinct . . . from the public" (436). These aristocrats (who may or may not be literally of high rank) are often called on in novels to infuse the quotidian with the promise of the exceptional, of Eliot's "glorious possibilities" ("Amos Barton," SCL 42). Potentially, a view like Lawrence's (it is the Carlylean history of Great Men revisited) is disastrous for fellow-feeling and an enlightened common life-the almost unquestionable aims of culture as Eliot and Woolf conceived it. They would commend instead a feminine heroism, not the detached individual's appropriation of glory. ${ }^{1}$

Eliot later called possibilities "handsome dubious eggs" (M 61), exposing the fantasy inherent in aristocratic heroism, attributed most often to young men: the fantasy that the one might possibly escape

\footnotetext{
${ }^{1}$ Lawrence's relation to feminism is certainly more complex than has been implied in such indictments as Kate Millett's, as Carol Siegel and others have shown. Lawrence's meditation, in the "Study of Thomas Hardy," on an originary gender dichotomy-a self-creating male principle, "Will-to-Motion," vs. a passive female "Will-to-Inertia" (448)-gives due respect to the female, recalling the ideology of influence. But Eliot and Woolf could not endorse the manly individual's prerogatives.
} 
the common lot of the many. Yet repugnant as such an exclusive fantasy ought to be for these women novelists, it is of course the fantasy they have realized in their own success. Not surprisingly, they do not seem content with feminine influence or the praise of an undifferentiated public. Romola and Orlando single out heroic figures exceptionally akin to the self-creating great women writers themselves, and to handsome, dubious aristocrats; they are unique, not one of many.

These romantic protagonists are freer from the "life of Monday or Tuesday," more removed from the authors' contexts, than most characters in the works of Eliot and Woolf. Romola, a fifteenth-century Florentine lady, while she responds to realistic conditions such as famine, preserves herself from the everyday almost as well as does Orlando, the magical English aristocrat who changes sex and who lives for centuries. This is certainly not the first time that the authors yield to the allure of high rank, of lords rather than loobies, as we note in such works as Eliot's "Mr. Gilfil's Love-Story" or Woolf's"The Duchess of Newcastle." Rachel M. Brownstein identifies the focus on the heroine in realistic fiction as in itself a holdover from "aristocratic romance" (xxi-xxii). Not only the exceptional protagonist but the cultivated author might figure as a kind of Lawrentian aristocrat, though without conspicuous will to power. Eliot's allegiance to the traditional role of the intellectual (never more manifest than in Romola) reflects her loyalty to an old order of landowning aristocracy, according to Deirdre David (167). Similarly, in Orlando Woolf hints at a biographical history of her own privileged place in a cultural aristocracy and parodies a learned gentleman in her narrator.

While Eliot and Woolf thus share with the protagonists of Romola and Orlando a detachment from the common life, the authors confront conflicting drives toward individuality and collectivity through these figures. The "visible madonna" and the immortal androgyne enjoy some of the supernatural privileges of romance as well as the aristocratic sense of embodying a public family history, yet like the other protagonists in these authors' works, they are schooled in some of the duties of feminine influence and fellow-feeling. Retaining their privilege, both protagonists also in a sense discover their womanhood by acknowledging their affinity for outsiders, for Lawrence's despised, undifferentiated masses.

Both novels, like their protagonists, are outsiders among the authors' works and in literary tradition. Romola, an historical novel or encyclopedic romance, spans the time from 1492 to the writer's present, 1863. In a lighter vein, Orlando too is a curious hybrid: a comic 
romance, mock biography, or literary history from 1553 to $1928 .^{2}$ Paralleling the central bildungsroman in each work are parables of the development of modern European culture and of the author's own vocation. Both protagonists are modeled on an eminent woman close to the author. Perhaps as a result, they have escaped being taken for the author's self-portrait. ${ }^{3}$ In both instances, the heroines present a vocation more limited than that of the grand old women of letters. The very elaborateness of their disguises broadens the scope for the authors' anxious speculations on the place of the woman of vocation in patriarchal culture.

Romola and Orlando register public history as private experience: the solitary protagonist encounters great leaders and events, while absorbing the commonplaces, the manners and weather of the times. Conversely, the novels identify an individual's private history with that of an entire culture, for the moment supposing that these aristocrats have the unmediated access to the (imagined) inner sanctum of such a culture that few individuals, and far fewer women, have had. Thus the tales focus not on the struggle to become a "great" woman of letters, but on the inner metamorphosis-Romola's need for a feminine social vocation, and Orlando's discovery of his/her sexuality-that is a synecdoche for that struggle. Let's pretend, the novels seem to say, that the "letters" are there for the asking: Romola always has known Greek, Orlando has seen Shakespeare as a boy. Even the greatness, perhaps, is easy, if you are born into the right family at the right time. But the womanhood? In a sense this is the characteristic that these aristocrats first acquire and then attempt to transform into a meaningful calling.

Different as the novels are, both were written either to certify or to celebrate the authors' high rank as novelists, addressing fit audience though few. Famous for different styles of inscrutability, these works evade the censure that a broadcast appeal for women's access to cultural history would arouse. The authors prefer not to be caught trespassing, yet they are uncomfortable in the passive role of sightseer. They desire the glory of the one and the power to sway the many.

\section{The Origins and Species of Romola and Orlando}

In 1860, on Eliot's first trip to Italy-most-favored nation for Victorians in search of high culture-her longstanding wish to write an "Italian story" crystallized into a plan (GE Letters 2: 463; Bonaparte 6),

\footnotetext{
"In the manuscript of Orlando, the boyhood episode is headed "1553" (Hoffman 437).

${ }^{3}$ Woolf seems partly justified in grouping Romola with Janet, Dinah, Maggie, and Dorothea as a "disguised," self-conscious version of George Eliot herself ("GE" [1919]
} 
somewhere between grave cultural study and the liberty of romance. Writing to her publishers, she took the stand of an enthusiastic scholar: "Florence, from its relation to the history of modern art, ... has stimulated me to entertain rather an ambitious project" (GE Letters 3: 300). The work would focus on "Savonarola's career and martyrdom. Mr. Lewes has encouraged me . . . , saying that I should probably do something in historical romance rather different in character from what has been done before" (GE Letters 3: 339; the subject appears to have been Lewes's suggestion [3: 295]). Under these austere auspices, however, lay that common British enthusiasm for passionate southern climes, for the Italy of gothic, of Corinne: or Italy. Perhaps there Maggie Tulliver (who could not bear to finish Corinne) would not have had to drown. ${ }^{4}$

Eliot was not one to wallow in Italian indolence, however, beginning to collect historical material on this very first visit. Back in England, she interrupted her daunting project to write "another English story," Silas Marner. She and Lewes later returned to Florence for more extensive research. Again and again she despaired from what she called "too egoistic a dread of failure" (Haight 348). The excitement of challenging the old prohibitions-in the spirit of Woolf's later call for writers to "trespass at once" ("The Leaning Tower," CE 2: 181) -was stifled for Eliot as she dutifully read through countless sources in the original (Haight 349-50; Bonaparte). Repeatedly, Lewes described her as "buried in musty old antiquities, which she will have to vivify"; he was dispatched to track down these "unreadabilities" while she labored at home like a subservient translator (or at best, a positivist historian) hoping for a spark of the novelist's genius. Lewes, believing that the great writer must master his material, enlisted John Blackwood's help "to discountenance the idea of a Romance being the product of an Encyclopaedia." The remote age and locale seem to have exaggerated her desire for accuracy; details pertaining to the most cherished traditions of modern Europe seemed less easily domesticated than the commonplaces of nineteenth-century rural England (GE Letters 3: 430, 457, 420, 474; Haight 353).

Eliot suffered more than the usual difficulties with Romola, difficulties only partly due to obdurate historical material. The undertaking raised doubts about her vocation: she was expected to deliver home truths rather than historical panoramas. She thought of publishing

157). Woolf linked Romola with her favorite, Middlemarch, as an innovation in the English novel that demonstrates "that men and women think as well as feel" ("GE" [1921]).

${ }^{4}$ Stephen claims that "Romola was . . . a cousin of Maggie Tulliver," "loftier" and learned. Instead of having her boat land safely, "she clearly ought to have been drowned, like Maggie" (George Eliot 136, 138). 
Silas Marner ahead of the Italian story, which could be serialized anonymously to avoid the predictable public complaints about an author's change of heart (GE Letters 3: 339). Her escape from the domestic novel entailed a kind of desertion of ordinary readers: "I myself have never expected-I might rather say intended - that the book should be as 'popular' . . . as the others. If one is to have freedom to write out one's own varying unfolding self, and not be a machine always . . . spinning the same sort of web, one cannot always write for the same public" (GE Letters 4: 49). Abandoning English subjects, her loyal publisher, and her accustomed public all at once may have seemed necessary for her to gain the privilege of variable genius rather than the duty of womanly reproductive labor.

Besides this challenge to her vocation, Eliot was faced with perhaps unconscious misgivings about her ideal of feminine self-sacrifice. Romola, unlike Maggie, survives her escape from "The Valley of Humiliation," her honor and independent selfhood intact, but she still must serve woman's mission. The less troubling English fable, Silas Marner, was at once closer to home and more impersonal. Silas like all Eliot heroines must learn the lesson of self-denying affection; like Romola he is reborn when he finds the lesson easy to learn. Both Romola and Silas, however, are removed from the Victorian woman's predicament: what question of individual rights, still less of women's rights, can there be for an antiquated common man or a lady in a Renaissance city-state? Apparently the common man yields his individuality more readily than the lady. The gold Romola is to forfeit-her pride, ambition, sexual love-may be a more doubtful price to pay, may even be, as Ruby Redinger claims, Eliot's "means of self-flagellation" to enforce the selflessness that she had been unable to attain (454).

The implied author's anxieties and the heroine's strain between aristocratic and feminine heroism undoubtedly contribute to readers' mixed impressions of the novel. Most often, criticism is directed at generic or historical crossbreeding instead of at the underlying gender conflict. ${ }^{5}$ Leslie Stephen articulated the common objection to Romola: "The 'historical novel' is a literary hybrid. . . . Either the historian condemns it for its inaccuracy, or the novel-reader complains of its dulness" (Eliot 126; cf. Levine, "'Romola,' " 82). Whereas the George Eliot of Adam Bede was able to "become a contemporary" of early nineteenth-century English rustics, Stephen continues, she could not

\footnotetext{
${ }^{5}$ Early reviewers for the most part received Romola with praise, believing it "as faithful as history, as it is great as romance" ([R.H. Hutton], The Spectator, 18 July 1863, in Lerner and Holmstrom 62). Yet most later readers have sensed a conflict in the author's aims, the accurate historical detail and cultural argument stifling the romance.
} 
as naturally become a quattrocento Florentine, given the unladylike brutality of the age. Stephen, like many critics of the novel, wishes to set aside "the historical paraphernalia" that fail to disguise the Victorian "spiritual history" in Romola (128-41; cf. Robinson 31-32). Thus Stephen reflects the very presupposition-that women must not trespass in men's history-that the novel exists to challenge. ${ }^{6}$ Yet though Renaissance Florence may not be essential to the tale, a substantial, tumultuous historical milieu at some remove from the novel-reader is absolutely indispensable to this revision of history as the biography of a great woman.

Critics have often explained the perceived disunity of the novel in biographical terms, citing Eliot's unusually personal defense of it (Greenstein 489; Sanders 9). To those who deplored a departure from domestic realism, she explained that "the 'Drifting away' and the Village with the Plague belonged to my earliest vision . . . as romantic and symbolical elements," yet she conceded that the attempt to mythologize cultural history may have led to "a more ideal treatment of Romola than I had foreseen" (GE Letters 4: 104). Against the contrary complaints about excessive historical detail, she explained that she simply may have gone too far in her usual quest for "as full a vision of the medium in which a character moves as of the character itself" (GE Letters 4: 97). Had readers not praised the substantial setting in The Mill on the Floss and Silas Marner? Were readers not themselves failing to follow the author's vision of the dependence of handsome dubious possibilities on determining social circumstances?

Romola was, finally, the test of her greatness: the one work she could defend "as having been written with my best blood, such as it is" (GE Letters 6: 335-36). According to John Cross, "The writing of 'Romola' ploughed into her more than any of her other books. She told me she could put her finger on it as marking a well-defined transition in her life. In her own words, 'I began it a young woman,-I finished it an old woman" " (Cross 2: 255). Andrew Sanders emphasizes what is often overlooked in this passage, that Romola was a formative as well as an arduous task; the "old woman" went on to the greater achievements of her later career (8-10). I would add that these images of personal transformation alert us to the autobiographical nature of

\footnotetext{
${ }^{6}$ Whether critics have found in the novel a rather bald Comtean or Feuerbachian allegory (Paris 214-22; Peterson 49-52; Bullen 425) or an artful work of historical criticism (Poston 356; Wiesenfarth, Eliot's Mythmaking, 146-47; Ronald; Hurley), they agree that the fifteenth and the nineteenth centuries meet in the work. Fleishman contends that the "application of . . . realism to the historical novel" failed to produce convincing links between character and background; the same actions could take place in any period (Historical Novel 159-60).
} 
the project: she remade herself, writing with her "best blood," as an heroic, self-sacrificing woman author. With Romola, she confirmed her standing as the Grand Old Woman of English Letters.

Orlando, like Romola, was conceived as "something rather different" in a genre never before broached by the author, and it too reveals the stress of the author's ambition and sense of failure. Even more than Eliot's novel, Woolf's has been read biographically, as an index to a personal transformation. Much as Silas Marner seems to have rescued Eliot from doubts that she would ever do anything worthwhile again, Orlando lifted Woolf out of a characteristic depression following publication of To the Lighthouse. Like the laborious Romola, however, the more reassuring work for Woolf raised questions of vocational and generic intention that were closely related to uncertainties about feminine heroism and the common life.

In 1927 Woolf toyed with a series of factual and fantastic projects: first "a new kind of play"; then "memoirs; have a plan already to get historical manuscripts \& write Lives of the Obscure" (compare Eliot's initial search among old books for the life of a great man); soon the project became "a Defoe narrative" yet a "fantasy" about two poor old women dreaming of Constantinople, with hints of sapphism. "My own lyric vein is to be satirized. Everything mocked. And it is to end in three dots ... so. For the truth is I feel the need of an escapade after these serious poetic experimental books. . . . I want to kick up my heels \& be off" (VW Diary 3: 128-31). Eliot, similarly torn between realism and romance (and between high and low art), also had moments of rebellion ("and suddenly burst my bonds, saying, I will not think of writing" [Haight 350]), but after an escapade in "lives of the obscure," Eliot fulfilled, in Romola, her duty to a history of the great. Orlando itself was the undutiful escapade-hence perhaps Woolf's flirtation with the little-old-lady alternative to the great tradition. Woolf fled not only the obligation to live up to high modernism but also a promise to write a critical history of the novel_-"that bloody book which Dadie and Leonard extort, drop by drop, from my breast" (this became "Phases of Fiction"). If she could not yield to them sentences written in her best blood, she could "dip[ ] [her] pen in the ink" and write "as if automatically, on a clean sheet: Orlando: A Biography" (VW Letters 3: 428). This might be a new kind of romanceencyclopedia; it could be history inverted, it could be a "life" beyond one finite self.

According to Leon Edel, it was Lytton Strachey who had first prompted Woolf's project; that innovator in the art of biography had suggested " something wilder and more fantastic . . . like Tristram 
Shandy" " (138-39; Moore 304). Strachey's instigation echoes Lewes's prompting of a new form of historical romance; the men of letters seem to train the women for the role of cultural challenger. Whether harnessed or unleashed, each woman must have felt that the stakes were high: her own right to the inherited genre she was told to transform. The men sanctioned what was also for both authors an independent impulse: to Vita Sackville-West, Woolf declared, "It sprung upon me how I could revolutionise biography in a night" (VW Letters 3: 429; Sackville-West, "Woolf and 'Orlando,' " 157), much as Eliot testified that Florence itself had inspired her.

Taking a holiday from tradition, Woolf felt she might also give the common reader a break; Orlando would be "very clear \& plain, so that people will understand every word" - "the one popular book!" (VW Diary 3: 162, 198). Perhaps accessibility would be a sign that the work was not one of her bids for the honors of high art. Ironically, Woolf succeeded in creating a popular work that remains a kind of private joke attesting to her intimacy with an aristocrat. Whereas Eliot defended a work excessively civilized, Woolf denied responsibility for a work run wild, "extraordinarily unwilled by me" (VW Diary 3: 168). Yet her playful revolution had become a torment reminiscent of Eliot's struggles with Romola: "I am rather depressed. Orlando so bad"; he, her protagonist, has become an incubus, "an old man of the sea"; "worse in his death than in his life" (VW Letters 3: 475, 471, 510). These complaints appear in letters to the living, female model of the protagonist, as though the usual dread of failure became mixed with her feelings toward her threateningly independent lover and toward powers she associated with masculinity.

Her fears were somewhat confirmed by the initial slow response when the book was published, though she claimed to have cheerfully put behind her a book not written with her best blood. ${ }^{7}$ Although Woolf subtitled the book "A Biography," "for the fun of" it, she immediately encountered the confusion of booksellers and reviewers as to how it should be classified (VW Diary 3: 198). ${ }^{8}$ More recently,

\footnotetext{
${ }^{7}$ Like Romola, Orlando brought its author unaccustomed prosperity, appeasing some of the authors' anxieties about public reception. Smith Elder offered $£ 10$,ooo for Romola, an unprecedented sum; due to Eliot's scrupulosity, the final terms were $£ 7,000$ (Haight 355-56). According to Quentin Bell, “Orlando sold 8,104 copies in the first six months. Financial anxieties were at an end" (Bell 2: 140).

${ }^{8}$ The labels ranged from Desmond McCarthy's praise-“a wonderful phantasmagoria" - to Arnold Bennett's dismissal-a "novel, which is a play of fancy, a wild fantasia, a romance, a high-brow lark." It has also been called "an allegory," "an autobiography," "a spirited prose epic of intellectual adventure," "her most elaborate love-letter," and an " 'anti-novel" " (Majumdar and McLaurin 225-37; Nicolson 3: xxii; Wilson 173).
} 
with the amplification of the biographical study of Woolf, the subtitle has been taken more seriously; Orlando is "about" Woolf's affair with Vita Sackville-West (Hawkes 53; Love), while it contributes to Bloomsbury experiments in biography. ${ }^{9}$ Woolf wrote of biography: "On the one hand there is truth; on the other there is personality. And if we think of truth as something of granite-like solidity and of personality as something of rainbow-like intangibility and reflect that the aim of biography is to weld these two into one seamless whole, we shall admit that the problem is a stiff one" ("The New Biography," CE 4: 229). The polarity is obviously gendered here, like the contrast in To the Lighthouse between "this delicious fecundity, this fountain and spray of life," and "the fatal sterility of the male . . . like a beak of brass" (TL 58). Eliot's loyalties to the masculine granite and Woolf's celebration of the feminine rainbow do not obscure their shared desire to weld the two in a narrative of the feminine in history.

Both Orlando and Romola, then, support a "personal" reading because as well as in spite of the authors' display of technical fireworks beyond gendered expectations for women's writing. Both works arose in response to a monumental task, the duty of the great woman of letters to explicate a dominant tradition, whether Renaissance history or the novel. Romola, Eliot's fourth full-length fiction, and Orlando, Woolf's sixth, come after each author had attained recognition and now wished to extend her range, in a deliberate swerve from what was expected. Both disguised autobiographies of the woman writer were conceived after the authors had delved into the family romance of their childhoods. In The Mill on the Floss and To the Lighthouse, conflicts between the genders had been resolved into momentary fluidity in the drowning of Maggie and Tom and the belated voyage to the lighthouse, with apparently lasting benefit to the authors (Beer, Past, 128; Knoepflmacher, "Genre," 97, 115; Redinger 33, 49; Schlack, "Fathers," 55-57; DiBattista, Woolf's Major Novels, 110; Gordon 202). Romola and Orlando brave the question of sexual difference with greater freedom, escaping the home setting to enter the new territory of their later works, particularly anticipating the historical breadth of Daniel Deronda and Between the Acts. In equally ambitious departures, Eliot and Woolf trespassed in forbidding forms, moving back in time, far afield, incorporating a lifetime's study of Western tradition in a revisionary guide to patriarchal history.

${ }^{9}$ For example, Harold Nicolson's Some People (1926) and The Development of English Biography (1927), Strachey's Elizabeth and Essex (1928) and other works, Vita SackvilleWest's Knole and the Sackvilles (1922), and Woolf's own essay "The New Biography" (1927), reviewing Some People (CE 4: 229-35; see Naremore 190-218; Philipson). 


\section{The Quest of the Woman of Genius}

How does the exceptional woman earn the right to trespass in cultural history? Like Romola and Orlando, the implied authors become sojourners in other times and strange lands, as though they had adapted the Grand Tour to a woman's purposes, always with the final return to the home. While training their aristocrats to side with the "others" in history, the authors preserve the privileges of high culture and the leeway of romance. Each protagonist is the darling of authorial Fortune, handsome and talented, innocently thrust into the public arena of history yet remaining reclusive and impressionable, more observer than agent. ${ }^{10}$ Such is the pattern of the preeminent instance of the Victorian woman writer in Italy. Woolf's response to Romola was mediated by her "reading," as well as Eliot's, of Elizabeth Barrett Browning.

When Eliot ventured into Italy and Florence, she followed Elizabeth Barrett Browning, whose famous escape from Victorian domestication bore the fruit of Aurora Leigh, the first fictional work in English on the development of a woman writer. ${ }^{11}$ Orlando, more venturesome, is another female künstlerroman following after the voyages of Barrett Browning (and Mary Shelley) as well as George Eliot (Knoepflmacher, "Exile," 112-15). Later, in Flush (1933), Woolf deflects reverence for female as well as male precursors toward that most obscure domestic outsider, the household pet. ${ }^{12}$ Flush, like the Victorian lady his mistress, is an innocent captive; in suppressing his nature to gain affection, he develops neurotic sensitivity. Both the woman poet and her dog come alive in Italy, beyond Victorian chained walks, much as Orlando changes sex in Turkey and unleashes her poetry after the Victorian age. The dog's perception of the glories of Florence is ren-

\footnotetext{
${ }^{10}$ Eliot had written a fable about a male Lady of Shalott, though Silas is reborn when love enters his room rather than dying by going out to seek it. (Although Jennifer Gribble does not refer to Silas Marner, she traces the figures of the solitary, the web, and the mirror in the works of Eliot and Woolf, among others.) Both Romola and Orlando could be further versions of the fable. The Italian lady descends from the tower, sees through the tirra-lirra knight, disembarks from her boat alive, and reascends the tower voluntarily, now free to pass judgment on events outside. Like Silas Marner, Orlando overcomes appropriative manhood and takes on the abilities of womanhood; like Silas, his transformations come about in trancelike states simulating the "deaths" of the Lady and Romola. Only when "he" becomes a lady is she able to ascend the artist's tower and weave her best poetry.

${ }^{11}$ On Eliot's response to Aurora Leigh, see Haight 185; Barrett Browning observed Eliot on the famous novelist's first visit to Rome (Haight 324). See Cooper; Woolf, "Aurora Leigh," CE 1: 209-18.

${ }^{12}$ Flush was the gift of Mary Russell Mitford to Elizabeth Barrett Browning (Moers 54) and hence a kind of mascot for the female literary tradition.
} 
dered in mock-Paterian tone: "Form and colour were smell; music and architecture, law, politics and science were smell." Flush outdoes the Victorians: "He knew Florence as no human being has ever known it; as Ruskin never knew it or George Eliot either" (138-40). Excluded from the culture that brings these pilgrims to Florence as a Mecca, endowed with heightened susceptibilities and a privileged but partial knowledge of the lives of poets, Flush is an apt persona for Woolf as outsider and literary descendant. At the same time, Barrett Browning's rise from chronic illness to artistic achievement, fame, and love has obvious significance for Woolf.

As Woolf presents it, Barrett Browning dictated both Eliot's enterprise in Romola and her own in Flush: "Savonarola's martyrdom here in Florence,' wrote Mrs. Browning, 'is scarcely worse than Flush's in the summer.'. . . The fleas of Florence are red and virile." The two English poets can only cure the spaniel by shaving off his coat, the sign of his "pedigree," till he feels "emasculated." But the humiliation frees him: "To be nothing — . . . To caricature the pomposity of those who claim that they are something - was that not in its way a career?" (141-43). Like the women writers, like Romola as well as Aurora Leigh, Flush reaches an acceptance of a feminine career in the "virile" climate of Italy, where the Victorians felt they could unite an ethics of work and self-sacrifice with a sense of play and physical immediacy ("religion itself was smell" [138]).

Like Flush, both Romola and Orlando dramatize the transaction between a creature of refined sensibility and the spirit of an age; with varying degrees of seriousness each woman writer shows that biographical history has mistakenly centered on great men. The human protagonists cannot remain as passive as the pet with his involuntary sense of smell, whatever may be expected of the passivity of women. ${ }^{13}$ The authors to an extent master the cultural encounter; these works record the authors' efforts to overcome a Flush-like misery before the spectacle of culture, while Romola and Orlando never appear to doubt that their quests are part of that spectacle. Though in each work the interest seems divided between the protagonist and cultural history, this division is instructive, as it suggests a refusal to accept the woman novelist's portion. Seizing the world for women, these works are preoccupied with historical figures and events, with the buildings and artifacts that give texture to a period, and above all with the "spirit of the age" that molds character.

\footnotetext{
${ }^{13}$ Flush "was violently sick" upon meeting Carlyle, whose own dog, Nero, seemingly attempted suicide-a facetious comment on a "dog's relation to the spirit of the age" (Flush 147, 151, 183-84) and on Woolf's relation to the Victorians.
} 
Savonarola in Florence, the Sackvilles at Knole: the authors recreate figures who enacted history in an age-old setting. The Duomo and St. Paul's still stand to mark the changing spirit of the ages since they were new. Like Eliot or Woolf, anyone might visit Florence or Knole and see many of the same frescoes or portraits. Yet both authors wrote a kind of guidebook to a sight no tourist would see unaided: Florence just beginning to decline from the Medici era, Knole just as Thomas Sackville was writing Gorboduc. They seemed eager to distinguish themselves from ordinary tourists. Whereas in inventing Cheverel Manor in "Mr. Gilfil's Love-Story" Eliot had been able to draw on memories of Arbury House, where her father had worked, she had to rely on research to construct a setting for the Florentine elite. Lewes was delegated to study the interior of Savonarola's monastery, which was off limits to women (GE Letters 3: 417; Haight 345); with Romola, we are allowed to visit the rebellious martyr inside. Woolf was intimate with someone who had been raised on the noble estate, and herself frequented such houses, but she both reveled in and resented a sense of being excluded from the libraries if not the luncheons of Oxbridge, as Eliot had been excluded from the monastery.

With all the air of being to the manor born, the narrators of both works take up the conventional personas of masculine writers of factfinding forms, history and biography. After Adam Bede, Romola and Orlando are the only works of fiction by either author to be narrated in a predominantly masculine manner. Though the convention of narrative history allows Eliot's narrator to know "What Florence Was Thinking Of" (chapter 35), he does not insist on his own absolute authority. Indeed, he emphasizes changing perspective and selective evidence, conceding the interpretive accidents of historiography without questioning the reality of a "universal history" to which all histories refer (White, "Interpretation in History," 281-87; Mink, "Narrative Form," 140-41). ${ }^{14}$ Woolf's personified narrator, the narrator who claims to be in charge (though much of the text appears to have been designed by another, impersonal voice, that of a subtle modernist), not only presumes a universal history but the possibility of a uniquely true account of it; with his nostalgia for positivism, he unconsciously parodies the objective mask Eliot respectfully dons. Even by his own

\footnotetext{
${ }^{14}$ Eliot meticulously displays successive frames of historical reference, from that of the modern visitor (reader) to that of Romola's contemporaries: to us the "buildings" in the Via de' Bardi are "quaint," to them, they are "too modern." Indeed, "historical memory" (the narrator's?) recalls "the famous houses of the Bardi family, destroyed by popular rage in the middle of the fourteenth century," the earlier version of history erased by a hostile audience, as it were (90).
} 
standards Woolf's narrator does a poor job: he is unequal to analysis and unable to criticize his sources, and he shuns "metahistorical" questions. His positivist claims founder before the text of someone else's life, which seems to spell the death of the author: "The first duty of the biographer . . . is to plod, without looking to right or left, in the indelible footprints of truth . . . till we fall plump into the grave and write finis on the tombstone above our heads"(65). Not only the inchoate truth of life but the polyphony of tradition overwhelm this narrator, who mouths classic authors pell-mell. ${ }^{15}$

The comic strife of this narrator suggests that Eliot could have "been saved all that nonsense" (VW Letters 2: 322), as the attempt at a serious, encyclopedic work must yield to the romance of any quest for knowledge or memory. The very documents themselves are squirming with bizarre life. Even Woolf's naive narrator shows, as Eliot's does, how history shifts according to the perspective of the observers, and he becomes increasingly defiant of authority and precedent: "The true length of a person's life, whatever the Dictionary of National Biography may say, is always a matter of dispute" (305-6). In spite (or under cover) of masculine narrators, both implied authors defy the exclusion of women and "others" from contemporary historiography. Even in taking liberties with the accepted facts, however, Woolf retains the conventional sequence of periods in English history. Instead of Eliot's citation of historical authorities, Woolf offers playful acknowledgments and an index. ${ }^{16}$ Moreover, though much of Orlando might be called modernist lyric aimed over the head of the witless biographer, the narrative as a whole displays what Woolf considered old-fashioned confidence in its referential transparency. In spite of some opaque embellishment, language here seems comparatively at ease with its mission of mirroring reality ("reality" itself generates the distortion).

While the authors adapt and modify the conventions of historiography, they also take on the matter of high culture, as we have seen in their association with Barrett Browning's Italy. No doubt about it, these novels are artsy, laden with cultural prestige. But of course there is doubt about it-doubt of the observers' authority, context,

\footnotetext{
${ }^{15}$ Among the allusions are those to Sir Thomas Browne (O 72-73, 81), Austen (139), Carlyle (78), Pater and Swinburne (47), Vita Sackville-West (109; in the ms., SackvilleWest's poem "The Land" and Thomas Sackville's "Induction to the Mirror for Magistrates" are quoted [Moore 322-31]), Virginia Woolf (98, passim), while Shakespeare, Pope, Shelley, and others appear in person and as consultants, in effect, on the spirit of the age (Schlack, Presences, 145-50).

${ }^{16}$ The dedication, "to V. S-W," the Sackville family portraits and allusions to their works, the resemblance of Orlando's house to Knole, and other details (Moore) establish a perhaps closer relation to factual history than in Eliot's text.
} 
reverence. The implied authors pose at times as art critics, docents, or even anthropologists. Both Romola and Orlando became the authors' only novels originally to be published with illustrations, images that seemingly would substantiate their historical fictions while inviting the reader to supply the context of contemporary versions of art history. ${ }^{17}$ Eliot invents prominent works of art, like di Cosimo's triptych, and Woolf playfully misidentifies the portraits of the Sackvilles: "Orlando as a Boy," "Orlando as Ambassador." Like anthropologists, they witness ritual spectacles: the quaint twirling towers and the newfangled "triumphal car like a pyramidal catafalque" (R 139), or the "pyramid, hecatomb, or trophy" of "ill-assorted objects . . . where the statue of Queen Victoria now stands!" (O 232). Both displays seem fantastic yet true, though Eliot's image is documented and Woolf's is an invented metaphysical conceit. The awe-inspiring cultural history that oppresses the heroines (Romola must be protected at home from the carnival of the streets, while Orlando's sense of feminine lack arises with that Victorian pyramid of objects) is made to serve the authors' designs. I would like now to sample passages in each novel that typify these designs, as the narrators refashion high culture and history to encompass the quest of the woman of genius.

Although there are more dramatized scenes in Romola than critics such as Barbara Hardy have allowed $(58,185)$, the general perception that this is a discursive rather than dramatic work seems correct. In Romola we receive the already received; often we are placed in the role of critic of an historic event or work of art presented to us as a palimpsest, with the political implications somewhat obscured. In one key scene-painting, Tito enters the Church of the Nunziata during a festival celebrating the Eve of the Nativity of the Blessed Virgin. Eliot has characterized the peasants, coming into Florence "like a way-worn ancestry returning from a pilgrimage on which they had set out a century ago" (193), as predominantly female; inside the church, this feminine crowd bows beneath the images of generations of dead men struggling for a place in history. Tito belongs in his androgynous way

\footnotetext{
${ }^{17}$ Eliot consulted with Frederic Leighton on the period details in his illustrations for Romola (Haight 360); it was standard for fiction published in the Cornhill to be illustrated. The spirit of Ruskin haunts this novel, whereas the spirit of Roger Fry haunts Orlando; as Witemeyer reminds us, Eliot was not a "formalist" or "forerunner of Roger Fry or Clive Bell" (171). Woolf asked Vita for photographs of Sackville portraits, and included pictures of her friend (VW Letters 3: 434-35). Three Guineas and Roger Fry were also published with photographs, which confirms the association of Orlando with biographical history more than with modernist poetics, though it burns with an aestheticist flame.
} 
neither to the common worshipers nor to the fathers-in-effigy. Tito sees the church

filled with peasant-women . . . the coarse bronzed skins, and the dingy clothing of the rougher dwellers on the mountains, contrasting with the softer-lined faces and white or red head-drapery of the wellto-do dwellers in the valley, who were scattered in irregular groups. And spreading high and far over the walls and ceiling there was another multitude . . . the crowd of votive wax images, the effigies of great personages, clothed in their habit as they lived: . . . popes, emperors, kings, cardinals . . . some of them with faces blackened and robes tattered by the corroding breath of centuries, others fresh and bright in new red mantle . . . the exact doubles of the living. . . . It was a perfect resurrection-swarm of remote mortals and fragments of mortals, reflecting . . . the somber dinginess and sprinkled brightness of the crowd below. (199-200)

Here is a narrator who has been to school to Ruskin; such passages, like ecphrases or narratives of paintings, are frequent in Romola (Stein 17-18; Stange, "Art Criticism"; Witemeyer 32, 157-73). Buried in a novel full of such bizarre antiquities, the passage may lose some of its force as social and historical commentary, and appear merely as a fleeting effect of chiaroscuro. But the spectacle of replicas of great men vying for a place "nearer the potent Virgin," in a grotesque simulation of their struggle for survival in life, is no benign reflection of the crowd below. The peasant women, in their hopeless devotion to the Madonna who might intercede for them with the Father, are figures of the collective human past that opportunists like Tito will tread down in their rise to power. The "resurrection-swarm" of damnable men of all eras foretells Tito's doom; a mob of political men will try to tear him limb from limb. Class, gender, and two orders of history, that of great men and that of the common life, are diagrammed in this tableau. As in the episode of the Great Frost in Orlando, extremes of the social order appear grotesquely fixed in a kind of cross-section, as though illustrating the platitude that high and low share the same fate. In both instances, however, the divisions are made only more obvious.

Though clearly operating under a broader license than the historian of Romola, the biographer of Orlando appeals to much the same sense of estrangement from a social order once considered natural. Any history or biography is a lark, a romance, because nothing could be more outrageous than the human past. Orlando's biographer cannot perceive this, even when evidence disintegrates before his eyes: "Just 
when we thought to elucidate a secret that has puzzled historians for a hundred years, there was a hole in the manuscript big enough to put your finger through" (119). To narrate the celebrations and riots in Constantinople when Orlando becomes Duke, the narrator must resort to the testimony of an officer's Defoe-style journal and a lady's Richardsonian letter, competing accounts biased toward either political maneuvers or the politics of the ballroom. Woolf's crowd scene "at the end of the great fast of Ramadan" closely resembles Eliot's at the festival of the Nativity, with the cultural hierarchy of imperialism added to the hierarchies of class and gender.

An English naval officer, John Fenner Brigge, records having climbed into a "Judas tree" to avoid the promiscuously mixed crowd roused by fireworks at the British Embassy. Brigge writes (the ellipses mark the holes in the manuscript), "There was considerable uneasiness among us lest the native population . . . fraught with unpleasant consequences to all, . . . English ladies in the company." But when no uprising occurs, Brigge experiences a moment of imperialist pride: the fireworks have "impressed upon" the natives the "superiority of the British. . . ." Brigge himself admires the superiority of the aristocrats inside the palace, though deploring the "conduct of Lady which was of a nature to fasten the eyes of all upon her, and to bring discredit upon her sex and country," whereupon Brigge falls out of his tree and is injured (127-28).

Brigge is an opportunistic observer like Tito, a social climber who enforces with his saber-rattling the oppression of the populace and of women of all classes, as he worships all signs of rank. He does not belong, and he has a fall-but it is the pratfall of a minor fool, whereas Woolf's mock hero continues for some hours to rise, very much like Meredith's Sir Willoughby Patterne ("Such a leg! Such a countenance!!" [O 129]) crossed with Byron ("adored of many women and some men," "he formed no attachments" [O 125]). As the hero continues to flourish, the task of scene painting is taken up, after Brigge's fall, by Miss Penelope Hartopp, whose epistolary effusions would have been breathless even without the effacement of the manuscript. Fragments of luxury remain: "candelabras ... negroes in plush breeches . . . pyramids of ice . . . [ . . ] jellies made to represent His Majesty's ships." Miss Penelope subscribes implicitly to the same scale of values as Brigge, gazing on "negroes" and "Lady Betty" as part of the delectable feast while presuming that His Majesty's forces will protect all ladies from all natives. Like Eliot's novel, Woolf's exposes the tensions in such hierarchical relations while exploiting the picturesque contrasts. 
The downtrodden crowd does revolt in both novels; when Orlando receives his coronet, order disintegrates and Turks burst into the Embassy. This preliminary outbreak, easily quelled by the British, heralds Orlando's transformation, suggesting a massive return of the repressed. First Orlando, having discarded "the insignia of his rank" (131), marries a gypsy woman by unofficial deed (much like Tito's alliance with Tessa), before falling into a trance. Then, the "terrible and bloody" Turkish rebellion breaks out in earnest, but Orlando's abdication of his role as statesman spares him the revenge of the rioters, whereas Tito is the chosen prey of the Florentine mob. In mockery of the entire code of honor and privilege that makes "the gentlemen of the British Embassy" choose "to die in defence of their red boxes" (133), Orlando sleeps till he is reborn as a woman, and then runs away to the gypsies. He has chosen to opt out like Romola or the childhood Maggie rather than to accept the masquerade of Western patriarchy, the swarm of men fighting for precedence over the mass of women and "natives" in mute subjection below.

Both the reliable and unreliable historians, as we may characterize the narrators of Romola and Orlando, suggest that the only enduring narrative is the private yet collective history of women such as the female peasantry. The biography of the public man, like the wax effigies, will become fragmentary and vain. Though in retraction from patriarchal history, however, both novels compromise with the conventions of aristocratic romance, as I have suggested, not limiting themselves to peasant-like realistic detail. Eliot deliberately recalls the tradition of romance with her errant protagonist's name. Although "Romola" is the name of an actual village near Florence (Haight 351), it also implies the feminine form of "Romulus," the founder of an empire. The only novel Eliot entitled after the heroine thus in effect feminizes the heroic or epic, much as Woolf was to do. Not incidentally, in preparation for Romola Eliot studied both Boiardo's Orlando Innamorato and Ariosto's Orlando Furioso (Bonaparte 20-24, 32), as though drawn to the repeated reincarnations of the romantic hero. In her early essay proscribing the errors of lady novelists, Eliot had offered a glimpse of the possibilities for comic updating that Woolf was later to exploit: "The Orlando of Evangelical literature is the young curate, looked at from the point of view of the middle class, where cambric bands are understood to have as thrilling an effect on the hearts of young ladies as epaulettes have in the classes above and below it" (318).

The romantic hero who changes with the chances of fashion, class, and the conventional desires of his female counterparts is certainly 
material for farce. At the same time, both Eliot and Woolf appear to have considered the idea of recurring heroic models as a serious reflection on possible designs for the self: some exceptional beings might be immortal or ahistorical, escaping the prescriptions of gender; or some types are inescapable, prescribed by timeless fate ${ }^{18}$ It is one form of the question of rebellion or duty that Romola repeatedly poses: is the individual capable of fashioning unforeseen destinies, or must she or he relive the old stories of the race? In both romances, we follow the career of a dutiful descendant who unwittingly becomes a rebel and an exemplar of what Ellen Moers calls "traveling heroinism," the "feminine substitute for the picaresque" (126-27). Orlando, allowed to dominate the text like no other character in Woolf's or Eliot's novels, is more strictly a picaresque figure than Romola, whose prowess is mostly exerted in confinement, the equivalent of a gothic castle. Both protagonists are emphatically bereft of "normal" family ties. Orphaned and disillusioned by the successive avatars of romance, doctrine, or letters, they attain a kind of self-determination extremely rare for women. Romola is provided with several father figures as a kind of insurance, whereas Orlando has only remote ancestors or senior poets toward whom he feels little anxiety of influence; in both works, paternal figures tend to die off, leaving the heroine, without the usual female foils, to devise her own lot.

Eliot and Woolf resist the easy cure for such solitude in the usual romantic plot. As a woman, Orlando resembles Romola in her choice of an androgynous counterpart, but her marriage to Shelmerdine is thoroughly open (she has her "career"), while Romola declares her legal subjection to Tito null and void well before his death (she is perhaps the least scandalous precursor of the divorcée). In the end, the protagonists arrive at a timeless present of feminine procreation that is also a retrospective on gendered destinations in patriarchal narrative. Though both novels end in a "scene" rather than an "overview," to apply Marianna Torgovnick's terms, a self-conscious "circularity" as well as a concluding formal and temporal distance from the

\footnotetext{
${ }^{18}$ Along with historic figures such as Francesco Cei, Eliot presents archetypes: Tito as resurrected Greek god (Dahl 83); Savonarola as Christ; Romola as the Madonna. See Karen Chase (304). Bardo the Stoic, Tito the Epicurean, Bernardo the Roman statesman, Dino the medieval Catholic, and Savonarola the spirit of the Reformation all influence Romola as she progresses toward the positivistic outlook. Disregarding the realistic limits of the lifespan, Woolf gives Orlando an eternal housekeeper, for a few hundred years a Mrs. Grimsditch, then a Mrs. Bartholomew (233-34). Shakespeare or Sasha, alive in memory, or Nick Greene, a man of letters in every age, reflect Woolf's playful literalization of typological metaphor; the romantic hero is for all time. As Vita writes of her Sackville ancestors, "Each [is] the prototype of his age," while "carry[ing] on . . . the tradition . . . [and] his race" (Knole 28).
} 
main action function as a kind of "epilogue" in each novel, a framing commentary on the role of the feminine in history (11-15). Whereas Romola merely stands in as a kind of fatherly mother to Tessa and the children (much as Aurora Leigh claims to be a second mother to Marian Erle's son to replace the missing father), Orlando is directly the mother of sons (no father seems necessary) and creator of a poem, "The Oak Tree." In both cases, the heroines nod to their forefathers' tradition, while expunging from that tradition the masculine penchant for ambition and violence. In a final tableau (whether Pre-Raphaelite or surreal), an admiring man approaches the woman whose reign is at last uncontested, though in the context of patriarchal tradition: Piero di Cosimo brings flowers for Romola's shrine to the martyr, Savonarola; Shelmerdine descends from clouds with the wild goose of Orlando's chase.

In spite of a liberating departure from familiar territory in both works, the ideology of influence is ultimately enforced: women should enjoy the fullest access to a privileged tradition without forfeiting their redeeming difference from men. Indeed, Romola learns to transpose her biological burden into a moral mission, while Orlando perhaps learns the inverse, to acquire the biological burden that corresponds with his/her moral mission. Yet conservative as Romola and Orlando may be, they belong in a feminist context. On the one hand, Romola appeared during the decade when women in Eliot's circle began to agitate for the vote, and Eliot subscribed $£_{50}$ "from the author of Romola" for the foundation of Girton, as I have noted. On the other hand, Orlando appeared during the post-war and post-suffrage decade of expanding opportunities for women, and in the same month in which it was published (October 1928), Woolf presented at Newnham and Girton the two lectures that were to become A Room of One's Own. In that manifesto she confronted the issues of tradition, education, and independence for women of creative ambition that had been raised in both Romola and her own Orlando. I turn now to follow more closely in each of these tales the steps whereby the trespasser inherits the property. A woman's education and vocation magically coincide with the fulfillment of tradition; history becomes the biographies of great women as well as men.

\section{Romola as a Woman's History}

As we have come to expect, Eliot's novel dramatizes a declaration of independence less for the heroine than for the author. There are many textual deflections from the female protagonist; the Proem, 
ostensibly symmetrical with the Epilogue, actually obliterates the feminine domestic sphere that presides in the end. With an interest in historical synchronicity that anticipates Orlando, the Proem declares "the broad sameness of the human lot" and overlooks difference. To support this broad humanism, Eliot resurrects a Florentine (d. 1492) in order to trace his impressions of Florence in 1863. The spirit was both a man who left a waxen image of himself in the Church of the Nunziata, and one of many in the carnival crowd below; an oppressor yet a reveler like both Orlando and Tito, he belongs in the "busy humming Piazze where he inherited the eager life of his fathers"-a zone alien to ladies. Though solidly bourgeois, the "Spirit" could make an amusing Orlando, alive across centuries and full of contradictory qualities: "of Epicurean levity and fetichistic dread; of pedantic impossible ethics ... . and crude passions." But imagining such cultural dialectic within one representative being does not lead Eliot, as it does Woolf, into a rhapsody on androgynous indeterminacy. Rather her narrator insists that "human conscience" binds "self-indulgent paganism" to public duty: "Public spirit can never be wholly immoral, since its essence is care for a common good" (44-48). About to chronicle the disastrous effects of opportunistic "public spirit," the narrator here protests too much, but he also anticipates Romola's eventual ethics of domesticated public spirit.

Eliot's narrative proceeds to detail the decadence of public men and the ascent of one heroine to supplant the Spirit of the Proem. Eliot's Florentine heroine is not Everywoman, however; she is a kind of fairytale princess sealed up in an ancient house with a blind father, the impoverished scholar Bardo. He lives among his fragments of antiquity as though communing "with the great dead" themselves (91-96). Like Casaubon-who also bears an ironic resemblance to the blind, daughter-exploiting Milton-Bardo has failed to complete his "great work"; he blames the desertion of his son, Dino. No daughter, he claims, can be "a fitting coadjutor," given "the wandering, vagrant propensity of the feminine mind ... [and] the feeble powers of the feminine body" (97). Denied the freedom of her father's library, Romola later must resign herself to "delicious influence" (170) and "the ready maternal instinct which was one hidden source of her passionate tenderness" (543). That hidden source may be something she can't help, but she is willing enough to stifle it at first: "I will try and be as useful to you as if I had been a boy," she tells her father. Bardo grants that she is remarkably learned for a woman and has "a man's nobility of soul," unlike her dead mother. He has kept her "aloof from the debasing influence" of women, a dubious advantage that leaves Ro- 
mola unschooled in her lot in life (100). She is not allowed to escape into acquired manliness; she must be a fit nurse for her father, and ultimately she must extend this function in public life. She is unable to replace her father's son except by marrying Tito, the young Greek scholar. As husband, he usurps the father's place and robs his wife and Florence of the classical scholar's collection of ancient relics. ${ }^{19}$

Romola begins in much the same position in the patriarchal structure as that other exotic aristocrat, Leonora Charisi, whose rage makes Romola's capitulation all the more striking. Daniel Deronda's mother insists on the ineluctable difference of sex even as she suggests that gender is acquired: "You are not a woman. You . . . can never imagine what it is to have a man's force of genius in you, and yet to suffer the slavery of being a girl. . . . [My father] wished I had been a son; he cared for me as a makeshift link" (DD 694). Eliot's narrator in Romola seems not to imagine fully Romola's consciousness of manly powers and female slavery; this docile heroine ultimately approves her role as patriarchal link (though I will argue that she has the last word on her failed fathers and mentors).

The contrast between Romola's manly "nobility of soul" and Tito's self-indulgent pusillanimity disturbs the sexual stereotypes that Eliot will not abandon outright. Tito "could easily be made to shrink and turn pale like a maiden" (164) ${ }^{20}$ Might Tito not be an incarnation of narcissism rendered poisonous by ambition, a forerunner of Gwendolen Harleth? (Daniel is certainly a male Romola: beautiful, sensitive, a bearer of a people's moral burden.) Although Tito offers Romola a life of luxuriant pleasure such as Maggie Tulliver glimpses in the boat with Stephen Guest, the Florentine couple soon confront their irreconcilable temperaments, like Maggie and her brother Tom. As in the earlier novel, in Romola the socially enforced division of labor exaggerates difference where there could be childlike union. Instead, Tito and Romola endure a nightmare of the Victorian bourgeois family, he utterly corrupted by public life, she imprisoned in the home without the consolations of wifely influence or motherhood. The male and female players have been miscast. Behind his armor of egotism, Tito is beyond influence (his literal armor is donned to ward off the rejected patriarch's revenge), while Romola appears incapable of Tessa's cozy

\footnotetext{
${ }^{19}$ See Emery on Romola's and Tito's efforts to replace Dino (85). Eliot's repudiation of the father figure is doubly accomplished by Tito.

${ }^{20}$ Woolf's father asserted, "Tito is thoroughly and to his fingers' end a woman" (139). Tito has the Protean as well as Dionysian qualities associated with effeminacy (Gilbert, "Costumes," 405): he changes costumes and roles with Orlando's freedom, whereas Romola cannot run away from her wifehood disguised in a nun's habit.
} 
devotion to husband and children. If Romola is perhaps too manly (for the gender stereotype), Tito is not man enough; like the ungendered Bacchus, he plays as though he will always be granted another life, and so he must die twice, first drowned by his "fellow-men" and then strangled by his stepfather, a fellow-demon (637-39). Romola in contrast overcomes egotism and so is granted another life after deathby-water, achieving sainthood without self-annihilation because the patriarchs die in her stead.

Though this tale appears to affirm the compensations of "moral evolution" for those who are misfits in the "worse share" of womanhood, it also exposes the failings of the father's law and allows the woman to resist it to a surprising degree. This rebellion is hidden under historical material apparently too weighty to be moved by one woman's desire for change. The objects that especially speak for patriarchal law seem at times to have more life in them, more agency than the heroine herself. The most frequently discussed symbolic objects, Dino's cross and Tito's triptych, make concrete the brother's and husband's attempts to steer Romola into different paths of devotion. The hyperactive jewelry and gems likewise perform as the will of tradition or the return of the past in this novel, as they do in romance generally (Wiesenfarth, "Antique Gems"; Levine, "'Romola,' " 8688 ), but here the treasures tend to subvert the law of the father. For example, the necklace Tito gives to Tessa leads Romola to rescue her, thus affirming a bond between wife and mistress in spite of the man. Yet Eliot makes certain we see Romola's reluctance to resist the exchange of women; when Romola removes her betrothal ring, she seems to be "rending her life in two" (391). In contrast, Tito supports his life of pleasure by selling the gems that could ransom his stepfather out of slavery; he cannot in the end rend his life in two, as his origins return by means of the gems to destroy him. Gems, valued for their rarity and the narrative of the past that they retain, also elicit an aesthetic response that for Eliot rouses anxiety (and for Woolf, delight): such pleasure invites "self-indulgent paganism."

Eliot tries to persuade her readers that public spirit, or collective historical progress, controls the egotistical designs of the individual: "As in the tree . . . each single bud with its fruit is dependent on the primary circulation of the sap, so the fortunes of Tito and Romola were dependent on certain grand political and social conditions which made an epoch in the history of Italy" (267). But this history of Italy is dead to us without our desire for the heroine's fulfillment and for the dreadful end of the hero's brilliant career: the tree depends on the buds and fruit. We have seen how the organic or horticultural image 
could be used to endorse "natural" gender difference; here it endorses as well the subordination of individuals to the collective growth. But Eliot's deterministic realism and fidelity to patriarchal tradition yield to rebellious romantic wishes. Romola, surrounded by archival commonplaces, serving as a disciple of a great historical personage, nevertheless seems one of the least historical of Eliot's heroines, fed by some nectar other than ordinary sap. She is exempt from women's domestic servitude: she has no chores, no children, and no trivializing ignorance. Eliot had praised great women who never neglected their domestic duties, but she invented a heroine who for a time is freed from such duties.

In what sense, then, does this oddly free yet dutiful heroine find her vocation as a woman? First, she does so by falling out of her domestic niche: once, "tenderness and keen fellow-feeling for the near and the loved ... had made the religion of her life" (391), but her father dies and Tito betrays her. Then, just as she strikes out on her own to become a scholar, a new father intervenes who instructs her in the tenets of womanly influence. From Savonarola she learns "sympathy with the general life," though she lacks an "innate taste for tending the sick and clothing the ragged" (463). It is a strange instinct that must be acquired-as Orlando discovers when she becomes a woman, feminine "graces" are "only attain[ed] . . . by the most tedious discipline," not "by nature" (O 157) - but it gives her something to do that would have just suited a Victorian lady like Dorothea Brooke. Indeed, fulfilling her resemblance to certain Victorian reformers, she becomes a public nurse. Savonarola seems to have Florence Nightingale in mind when he defines Romola's vocation: she is to "labour for the suffering and the hungry . . . as a daughter of Florence. . . . I desire to behold you among the feebler and more ignorant sisters as the apple-tree among the trees of the forest, . . . as a lamp through which the Divine light shines the more purely" $(438) .{ }^{21}$ Like the mythic Nightingale, Romola is to domesticate public space, thereby framing rebellion as a duty in the manner of many Victorian ladies. Even the myth of the lady with the lamp was a quiet retort against patriarchal mismanagement, proving what a lady could do.

Romola as powerless daughter and wife experiences the wrongs that Bodichon and others campaigned against in the 1840s-6os, particularly

\footnotetext{
${ }^{21}$ In both instances the quasi-divine leader of a sisterhood of mercy is not apparently much suited for domesticity. Nightingale spent much of her life as a bedridden invalid spurning her own family but consulted by statesmen. Mary Poovey has most recently illuminated the contradictions in this eminent Victorian (164-98), contradictions very much like the man-womanly Romola's.
} 
the injustice of the education system and property laws, but Eliot's novel stands apart from the very causes it makes a case for. Instead of pursuing her scholarship, reclaiming her father's property, or confronting her husband's double standards, Romola abandons the political crisis and puts out to sea in an alienated trance rather like Orlando's. She is reborn as the "Holy Mother" (641-44) for the plagueridden village, a community unlike the gypsies that honors the heroine more than her native society ever would. Like Nightingale, then, Romola is apotheosized after one spectacular foreign campaign of nursing, whereupon she retires to her home-but not to administer imperial affairs. It is not that Romola can only take things personally, like a woman. She does take the downfall of her mentor Savonarola as a calamity more personal than political, but she has long since lost the narrow domestic feeling that would grieve at Tito's infidelity or death. Rather, her selfless politics are confined to personal strategies. In the end she makes it her business to tend Tito's home and to keep sacred the personal memory of Savonarola. Like a Renaissance Josephine Butler, who crusaded against the Contagious Diseases Acts (which authorized the policing of women in military districts to make prostitution safe for men) and who founded a home for prostitutes, Romola subverts the effects of the double standard by uniting with the other woman, while at the same time retaining the forms of paternalistic faith. But unlike either Butler or Nightingale, she never campaigns for public power.

In her quest, Romola has learned to be an earthly madonna - that is, "woman" in Victorian terms - but she has also triumphed over the patriarchs, as the last scenes of the novel make clear. Savonarola's execution takes place in the final chapter before the Epilogue, titled "The Last Silence." The heroine inevitably imagines herself in the place of the martyr, but he takes this part in her stead. Still withholding her sympathy for the masses, she witnesses the spectacle as a lady at a window high above the crowd-"the baser part of the multitude delight in degradations," but not she. She repeatedly covers her eyes as Savonarola is brought out, but at the last "she only saw what he was seeing . . only heard what he was hearing. . . The moment was past. Her face was covered again, and she only knew that Savonarola's voice had passed into eternal silence" (670-71). Thus ends the action of the novel in 1498. Yet the witness survives, because what really matters is not his suffering or his death, but his silence. No longer is it his voice that holds her within the city of her fathers, but her own.

Why is the ensuing portion of the novel not narrated from the point of view of a male bourgeois Spirit of 1509, like the Spirit of 1492 in the 
Proem? Why alternatively does the narrator himself not have the last word in person? Because the novel needs the asymmetry of a woman's speech against the voices that have predominated since the Proem. Like the highest ranking survivor in a tragedy, Romola has the last word. As the title of the novel reminds us and the Epilogue quietly insists, the great man's story is not the whole story. The Epilogue is a tableau that pays decorous tribute to the patriarchs while foregrounding Romola's authority.

First, we see that Savonarola has been reduced to a small portrait over a wreathed altar. Then we focus on the other women: first Tito's clever daughter, who like Maggie "toss[es] her . . . hair out of her eyes"; then Tessa, "not very clever," plump with "childish content"; then Romola's inadequate mother-surrogate, cousin Monna Brigida, sleeping her life away. ${ }^{22}$ The rather scornful image of women here sets Romola apart from them, closer to the men, yet triangularly facing both ("Romola sat nearly opposite Lillo," both of them "farther off" from the women). Romola, though she has gained "placidity," is still beautiful and very much awake; from the beginning she has rejected parasitical idleness. She seems to turn her back on history, gazing "absently on the distant mountains."

A dialogue begins when Lillo, tired of memorizing a poem addressed to the ideal future statesman (a poem by Petrarch, one of Bardo's approved poets), asks Romola what he should be when he grows up. "Mamma Romola" suggests that he emulate Bardo, who is not in fact Lillo's grandfather but only the second foster father whom Lillo's father betrayed. Lillo, the raw material of another Tito, says he would rather not die a defeated old scholar; he wants to be "a great man, and very happy besides." Romola, in a voice suspiciously like George Eliot's, admonishes him that the "highest happiness," enjoyed by the "great man," comes of "having wide thoughts, and much feeling for the rest of the world as well as ourselves. . . . We can only tell [this sort of happiness] from pain . . . because our souls see it is good. . . . No man can be great-he can hardly keep himself from wickedness-unless he gives up thinking much about pleasure or rewards." This doctrine grants a painful sort of happiness only to those who do not think of themselves as Bardo always did; to reflect on one's greatness is to fall into wickedness. Romola summarizes Tito's career as an illustration of "calamity falling on a base mind."

\footnotetext{
${ }^{22}$ In these childish, dozing figures, it is tempting to see Eliot's judgment of her "husband's" very plump other wife, Agnes Lewes, whom she may not have forgiven as readily as Romola does Tessa.
} 
According to Romola's definition, the only great man in the bookthe only figure who has abandoned self-interest in a grand cause-is Romola herself. She "never for a moment told herself that it was heroism or exalted charity" (656) to rescue her base husband's "other wife" and children.

It is helpful to return a little to consider Savonarola's egotism, the besetting sin of the heroically great. Romola, in the chapter before the frate's execution, was a critical reader of his confession: his entire career (the doubtfully authentic document states) was designed to make him "for ever famous." He always claimed that "the cause . . . should triumph by his voice, by his work, by his blood. In moments of ecstatic contemplation, doubtless, the sense of self melted in the sense of the Unspeakable." But unlike Romola, and perhaps more like Eliot herself, he cannot sustain self-abasement; he desires "preeminence" (664-65). Eliot too strives in this novel for preeminence, serving the cause in her own voice, writing with her best blood. Romola is more fortunate than great egoists like Savonarola and Eliot, because she can be great without knowing it. For though she is not to be grouped with the feeble women in her domestic circle, she has that dedication to others which seems more readily imagined in woman than man. If Romola had ignored Savonarola's instructions on how to become the lady with the lamp, if she instead had made her way to Venice on her first venture to compete with great learned men, her martyrdom (like the Alcharisi's) would have been most severe. Having given a thought to her own greatness, she would have forfeited its purest rewards.

In the Epilogue, Romola neither mentions her own lost ambition nor tells Lillo of his parentage or his father's crimes. Romola's little matriarchy is founded on the secret of illegitimacy and the lie that Romola has no desires. Thus what may look like the praise of famous men is rather a refusal to condemn the fathers' glaring failures. Filial piety has been a very unreliable principle throughout the book, not only because every father has been an egotist more or less hostile to his child's life, but also because the fathers have died in shame, Savonarola the last among them. Moreover, along with filial piety, the novel has preached a competing doctrine: "The law was sacred. Yes, but the rebellion might be sacred too" (552). Romola sees that she, like Savonarola, faces a call to "the duty of resistance" (540). Antigone's confrontation with two incompatible goods is reenacted here. The child who wishes to grow to the father's stature in patriarchy must rebel, but the female child seldom succeeds in replacing the patriarch. 
The futility of women's rebellion lends them an appearance of selfless obedience, of moral superiority, though like men they may desire preeminence. But why should the fathers, the proponents of sacred law, be honored by the daughters who obey that law better than they? So asked the Victorian women's movement, so implicitly asks Romola.

In a curious acknowledgment of the patriarchal construction of gender, Eliot shows that Romola needs a man to teach her a woman's supposedly natural "fellowship with suffering" (396), her part in the "common life" (433). But when her instructor vainly identifies his cause with God's, she protests: "God's kingdom is something widerelse, let me stand outside it with the beings that I love" (578). This rare moment of outspoken confrontation exposes her competing egoism, which must be washed away before the heroine can pose as a truly great woman in the Epilogue. Yet in her last words we sense that she is still carrying out her duty of rebellion, standing outside the patriarch's kingdom in her own domestic paradise; here she may forgive men because they are absent. Savonarola has become an image as fixed as any madonna; the artist Piero di Cosimo and another man approach outside, bringing flowers to the shrine, far more in honor of Romola than of the martyr.

Romola herself admits, in the final speech to the boy, that Savonarola is only to be worshiped through the medium of love, not through the fathers' doctrine. "Perhaps I should never have learned to love him if he had not helped me when I was in great need" (676). The greatest help he offered was to teach her the failings of the law of the father. He is sacrificed to wash away the sins of Romola's, and perhaps of the author's, own rebellious ambition. In the Epilogue, the great woman has become the link she might have been if she had been a son, teaching Lillo as her father taught her, but the tradition has been subtly modified by her influence.

\section{Orlando and the Quest for Womanhood}

If Romola's greatness lies in her having outgrown what Woolf calls "romantic . . . individuality" ("GE" [1919] 154), Orlando's greatness surely lies in refusing to grow up (in several ways Orlando is a highbrow Peter Pan). ${ }^{23}$ Unlike Eliot or Romola, unlike Woolf herself, this

\footnotetext{
${ }^{23}$ In an unpublished paper, Ellen Barber has traced many fascinating parallels between Orlando and Alice in Wonderland - another parable of the anxieties of growing up. Paul West briefly links Woolf's epistomological play in Orlando to Lewis Carroll (99).
} 
romantic individualist never has to face opposing duties of obedience and rebellion, never has to play Antigone or Oedipus to fatherly prohibitions. Yet in the transformation from man to woman, the heroic type does temper romantic individuality; this is the story of a moral progress not unlike Romola's, in spite of the delightfully amoral byplay. Along with the deconstruction of gender and identity, there is the development of a woman's mission originating in the biography of the questing woman writer. In its "personal" relevance, as I have suggested, Orlando may be taken seriously, at the risk of playing the straight man, like the narrator who never gets the joke.

Woolf herself, like Romola, was raised in her father's library as in "the heart" of one of Eliot's novels, "cloistered like a place of worship, but that she no longer knows to whom to pray" ("GE" [1919] 159); whereas Romola's husband dismantles the library, Woolf inherited it intact (Silver, Introduction, Notebooks, 26). Though his was a more tolerant age, Leslie Stephen could be a kind of Bardo toward his talented daughters. In autobiographical writing, Woolf charges that such oppressors were indulged because everyone accepted two precepts, that "men of genius are very ill to live with" and that "the woman was his slave" ("Sketch" 124-26). If there is a duty to rebel against such precepts, Woolf nevertheless venerates the father's library and pays tribute, even in her most playful fiction, to shades of her father (rather as Romola honors Savonarola's portrait). Orlando can be seen as a woman's effort to be as useful to the father as if she had been a boy, though in an inversion of the academic manner that Stephen criticized in Romola.

At the outset Orlando's biographer, like the narrator of the Proem, affirms the "sameness" of a masculine norm of humanity. Yet Woolf's narrator is more elitist than humanist, subscribing to the chivalric code as he introduces Orlando practicing his swordsmanship on the "head of a Moor" that resembles a "football." Vowing to emulate his forefathers, Orlando "would steal away from his mother" to abuse this adversary, "fastening [the skull] with some chivalry almost out of reach so that his enemy grinned at him through shrunk, black lips triumphantly." The author may invite our laughter at such brutal and racist chivalry, but the narrator blindly adores the hero. He rhapsodizes, "Happy the mother who bears, happier still the biographer who records the life of such a one! Never need she vex herself, nor he invoke the help of novelist or poet." That the male biographer should outdo the female creator-the mother or the author-of the hero is a fine commentary on the presumption of patriarchal authority (and Orlando's mother and Woolf the woman novelist are both effaced). 
This biographer anxiously suppresses any sign of non-exploitive heroism - that personal "riot and confusion . . . which every good biographer detests" (13-16).

Woolf's hero enjoys the advantages not only of Romola's beauty, intellect, and transcendence of the petty conditions of history, but also of wealth and manhood, and hence a freedom denied to heroines (and the woman author). Even in the age of a powerful queen, Orlando's potency is derived from his Turk-slaying forebears and his identity as male heir. His sister, like Shakespeare's, would not have been allowed to act the heroic part. With more than 365 rooms of his own (SackvilleWest, Knole, 4), he is free to choose the literary life. Woolf romantically softens certain features in this portrait of Vita and waffles between the "nature" and "nurture" accounts of difference. The real descendant of the Sackvilles, although there could be some doubt of her sex, was barred from the inheritance of Knole. In the fiction, Orlando is able to inherit her estate in a vision of legalized androgyny. Although the narrator (in his or her more open-minded phase) declares that "in every human being a vacillation from one sex to the other takes place," and speculates that gender is only superficially signaled by customary dress, he or she also insists, "The difference between the sexes is, happily, one of great profundity" (188-89).

The difference between Orlando and you and me is profound indeed. He enjoys the charms of an elaborately preserved history without sensing its burdens, and he can commit every social transgression-even crossing class boundaries-without a troubled conscience. An instance of Orlando's privilege is his relation to romantic objects, the fragments of overdetermined narrative resembling the triptych, cross, and gems in Romola. Queen Mary's prayerbook and the tapestries and relics at Knole follow Orlando through the centuries, but they condone rather than restrain his every whim. Gems, the correlatives of characters' rarity, beauty, and connection to the past, here celebrate a Paterian jouissance, though always appropriate to the social code. At first Orlando burns with as gemlike a flame as Tito, squandering a patrimony in such indulgences as "illicit love in a treasure ship," among bags of rubies (30). Becoming a woman, Orlando retains her hedonism, bartering the "emeralds and pearls . . . of her ambassadorial wardrobe" to play gypsy; at the same time the gypsies destroy her pride in property and rank ("a Duke . . . was nothing but a profiteer or robber" [140, 147-48]), and they prove hostile to a woman's (or Romantic poet's) contemplative love of nature. ${ }^{24}$

\footnotetext{
${ }^{24}$ Opening the Byron that Carlyle ordered closed, Woolf makes her Byronic hero take on the marginality of women and the orient more permanently than Don Juan does in the harem. Her mock-epic is to the moment, like Joyce's, but with an exotic difference
} 
Orlando remains at heart an English aristocrat, and with the shifting moods of history she rededicates herself to traditional hierarchies. She wears Queen Elizabeth's gift of a "vast solitary emerald" as a stamp of rank and independence until the nineteenth century, when she feels "a ring of quivering sensibility about the second finger of the left hand"; at last sharing Romola's mores, she feels she is only half a woman without a wedding band (239-41). Yet she cannot subject herself to a chivalrous wooer like the Archduke. Only a fellow romantic venturer, Shelmerdine, can fulfill Orlando's "womanly" need for romance without suppressing her "manly" ambition; in this extraordinary marriage, she may release the youthful gemlike passion that more responsible ages had dimmed. In the end she greets her husband with ready love: "Her pearls burnt like a phosphorescent flare in the darkness" (329; Sackville-West, "Woolf and 'Orlando,' " 157; Fleishman, Woolf, 140-45).

The narrative that these gems tell in miniature is highly ambivalent toward its own disruption of traditional order. This apparently freewheeling romance also implies a progress in English cultural history and in the development of a representative individual (albeit with some nostalgia for the blades and wits of early periods), with preference for the mature woman of the present day. At the same time, Woolf's romantic world is more rebellious than obedient, taking liberties with determinacy that Eliot's narrator cannot allow. Indolence, sexuality, defiance have no victims like Baldassarre or Tessa, and meet no punishment; the past plays along rather than tracking anyone down, and all commonplaces are gemlike exotics. Only in the nineteenth century are the pressures of the double standard and of feminine duties brought to bear, but like Romola, Orlando sidesteps domestic slavery.

With every reason to prolong those moments of alienation in Whitehall (RO 101), Orlando instead creates a sanctum within the old order from which to contemplate the errors of patriarchy. This feat is the hero/heroine's greatest achievement: by becoming a woman, Orlando fulfills the duties of feminine heroism, serving a collective destiny and preserving an ancestral home. The ideology of influence has been partially restored after a day of misrule. The misrule is genuine, and manly heroism will never be the same, but a lingering mystique of feminine and aristocratic charm remains. How does this wayward pilgrim's progress arrive at a destination so like its beginning, and rather like Romola's ending?

(de Almeida 61; DiBattista, "Joyce, Woolf," 111). Unlike Maggie Tulliver, and unlike her boyish former self, Orlando has no desire to master these pagans (a woman does not wish "to make an Englishwoman" of every "negress" [RO 52]), though continuing to regard them as Other (Stimpson 136). 
Much as Romola awakens from the sea as a madonna in a strange land, Orlando is transformed during a trance in foreign parts, attended by three madonna figures representing "Purity," "Chastity," and "Modesty." Yet instead of blessing the heroine's rebirth, these ladies strive to veil some obscenity and must be driven away by trumpet blasts of "TRUTH" (one of the male "Gods" [136-37]). The old fairy tales must give way, it seems-very liberating for the abject female figure in such tales, but still not a guarantee of free agency, since a patriarchal reality principle can do the work of a stepmother's curse. Orlando will not have to be a daughter asleep in a tower, but she must give up swashbuckling and learn how to be rescued. There are compensations for such passivity, she thinks on her voyage toward eighteenth-century England. Anticipating Three Guineas, she meditates on the advantages of woman's "poverty and ignorance" and the privilege of forgoing exploits for the sake of "contemplation, solitude, love" (160). Such outsider's pride is fragile, and Woolf can only preserve it apart from the frustrations of everyday domestic life. Orlando unlike Romola never holds still for an Epilogue, and constantly reverts to "manly" desires; her life continues to be a vacillation between contemplative solitude and immersion in city turmoil.

Back in London three charges are brought against her: "(1) that she was dead, and therefore could not hold any property whatsoever; (2) that she was a woman, which amounts to much the same thing; (3) that she was an English Duke who had married one Rosina Pepita," whose three sons declared the Duke dead and claimed their inheritance. Her indefinable identity in itself deemed a crime, she retires "incognito or incognita" to the country (168), like Romola evading the power plays of the state in a quest for her own vocation. Yet Orlando's vocation is to be heir and poet without the belittling suffix "ess" on either title, and to find "life and a lover" (185). For all this, she must venture out into the spirit of the age and make the most of her freakish indeterminacy. She bemoans the artifice of "Society," romps with the men of letters in the salons, quarrels with their misogyny, and for relief dresses as a man to gain the freedom of the back streets, where she befriends the whores.

When the fog of the nineteenth century settles, however, she feels she must cease cross-dressing, adopt the crinoline, and "take a husband" (243). Gender has come to be more insistently defined, but she and the Shelleyan Shelmerdine are able to strike a compromise with the marital spirit of the age. They unite the woman-manly adventurer and the man-womanly poet ( $\mathrm{RO}$ 108), each blending aristocratic and feminine heroism; to each lover it is "such a revelation that a woman 
could be as tolerant and free-spoken as a man, and a man as strange and subtle as a woman" (258). ${ }^{25}$ Yet there is a distinct division of labor: Shelmerdine "had explored the East" (251) and compulsively rounds Cape Horn-in other words, he is an agent of the Empire-whereas Orlando waits at home, her ambassadorial ventures behind her.

Since the protagonist has ceased to play an "important part in the public life of his country" (119), she has increasingly viewed herself as object ("becoming a little more modest . . . of her brains, and a little more vain ... of her person" [187]), while the naive biographernarrator has increasingly doubted his command of his subject. What could be more ineffable, more absent, than the woman and the writer? In a triumph of impersonality, Orlando fulfills a woman's mission by marrying, thereby becoming reconciled with "the spirit of the age"; this reconciliation promotes her mission as writer: "She could write, and write she did" (266). These acts stun the patriarchal biographer, the rival writer who wants to define "life" in terms of action and external fact.

He resorts to gender convention: "When we are writing the life of a woman, we may, it is agreed, waive our demand for action, and substitute love instead" (268). ${ }^{26}$ Yet, in spite of her claim that womanhood entails contemplation and love rather than action, Orlando foils the biographer's old love plot, declining to slip off her petticoat for a gamekeeper as D. H. Lawrence would have her do (269). With this, as Orlando's opus nears completion, the old biographer is completely overcome by the woman writer's wiles: "Let us go, then, exploring, this summer morning, when all are adoring the plum blossom and the bee" (270). Like the protagonist, the narrator in a kind of trance changes sex, and begins to develop what might be called the lyrical epic combining collective history and private emotion (in the wake, not incidentally, of Aurora Leigh, Barrett Browning, and Woolf herself). ${ }^{27}$

Orlando has borne her poem, "The Oak Tree," much like Romola's pursuit of a higher good, through successive cultural phases, and has disguised "something highly contraband"-her freethinking ambition-by "dexterous deference" to the bourgeois Victorian definition

\footnotetext{
${ }^{25}$ The lovers are curious and enthusiastic - "they had to put the matter [of each other's sex] to the proof at once" (258)-diverging from conventional romantic, appropriative love. This brush with the erotic is unusual in Woolf's fiction, but as in the union of Esther Lyon and Felix Holt, it displays the innocence of children and angels.

${ }^{26}$ "The truth is that when we write of a woman, everything is out of place . . the accent never falls where it does with a man" $\left(\mathrm{O}_{312}\right)$.

${ }^{27}$ Woolf wrote in her diary as she finished the manuscript of Orlando, "I feel more \& more sure that I will never write a novel again. Little bits of rhyme come in" (VW Diary 3: 177).
} 
of the lady and the writer (265-66). How to carry manly assurance over into the womanly sphere of contemplation without losing an aristocratic sprezzatura would be a challenge, Woolf suggests, for any writer in a professionalized, self-conscious age, but particularly for a rarity like Orlando, a lady who can recall being a pageboy for Queen Elizabeth when writers were servants to the great. Orlandowill always be "out of it"; her art for art's sake will always be a throwback, a distillation of a precious history but never quite the full Woolfian articulation of the common life. Woolf adores and condones this privileged withdrawal from the thoroughfares of history, but as her own work concludes she dedicates Orlando's inner life, if not Orlando's art, to a kind of public service.

As Orlando approaches the present she perfects her understanding of a tumultuous common life within us all. She tries to marshal her "more than two thousand" selves under "the Captain self, the Key self," recognizing the insubordination of identities and the synchronicity of all times in biographical history $(310-14,305)$. The narrator still strives for a more definite order: "The reader can judge from overhearing her talk as she drove (and if it is rambling talk, disconnected, trivial, dull, and sometimes unintelligible, it is the reader's fault for listening to a lady talking to herself; we only copy her words as she spoke them, adding in brackets which self in our opinion is speaking, but in this we may well be wrong)" (310). The modern woman writer insists on her own style of interior monologue. Though the narrator still clings to chivalrous notions of a lady's privilege, Orlando has (like a truly great woman or man?) become permeable to other identities and the pulsing ordinary life beyond such privilege. She recognizes that she may be a spoiled snob, though she likes "peasants" and rural life; she drives through a "crowd of market people" unnoticed in spite of her fame and rank (310-12). Like Flush shorn of pedigree, Orlando might make a career out of being "nothing," mocking those who claim to be "something"; she might become part of everything she has met. But like Romola posing for the portrait of a great woman, Orlando still has too much romantic individuality to commit herself wholly to an influential disappearing act.

\section{The Heroine's Progress}

In her concluding retirement, Orlando has achieved more in her own right than Romola can claim to have done; she has inherited her ancestral home, she has remained a happy wife and has become a 
mother (though without giving these roles much thought), she still has plenty of fun, and she is a well-known poet, winner of the Burdett Coutts prize. There is a covert social comment in this last detail, since the rise of female reformers like Angela Burdett Coutts (the great philanthropist and friend of Dickens) coincided with the feminist movement, and Orlando's independence marks a great social reform. Yet whereas Eliot's aristocrat was driven by the noblesse oblige of a Burdett Coutts, Orlando has never made bandages or dispensed soup; she is the spirit, not the conscience, of a female literary tradition. Like Romola, Orlando retreats to rest on her laurels and pass on the patriarchal heritage: "With my guineas I'll buy flowering trees, flowering trees, flowering trees and walk among my flowering trees and tell my sons what fame is" (312). The suggestion that both protagonists reign over a flowery domestic world in which they define fame or greatness for male successors seems to dampen hopes for further female quests. What women might emulate their example, might trespass so far? Yet both heroines have fulfilled their aristocratic destinies in spite of being daughters. In the final pages, Orlando welcomes the return of Queen Elizabeth's ghost and Shelmerdine, as though in 1928 (a far cry from 1509), the woman's heritage and desire may both be fulfilled.

The implausibilities and longueurs of Romola, the raucousness and lacunae of Orlando reflect conflicting impulses toward affirming a providential process or a miraculous heroine. Seizing more license than Eliot, Woolf still relies on readers' shared sense of "real" history. Against a deterministic sequence of change, in which the common people serve as material sculpted into history, Eliot and Woolf offer the rare instance of escape from the predictable (Beer, Past, 117-37). Romola and Orlando are heroic anomalies, aristocrats who earn their inheritance in spite of patriarchal law. In womanly ways, they gain their place among "lives of the obscure," almost as much a part of the medium of racial memory as are the old-fashioned peasants near Florence or Knole; but they remain like their authors keenly aware of their difference from the masses. Outliving the men who have their political day, Romola and Orlando serve as vessels for the spirit of the age and all ages, subtly influencing "the growing good" (though the good is more indulgently construed in Woolf's text). These heroines escape temporal definition, like the relics that have survived into the reader's present, and as a result they beg the question of female vocation: not only the tradition, but the greatness and finally the womanhood are compatible givens in these make-believe worlds.

The authors, implied and actual, stand above the circumscribed 
achievements of their characters. Whereas Romola consecrated herself to future generations, George Eliot gratified her own ambitions of learning (few novels have been as learned), success, recognition, and-for the living woman-domestic happiness outside patriarchal marriage laws. Perhaps Eliot's emphasis on serving the common people in Romola and in the next novel, Felix Holt, is offered as atonement for her freedom as outsider, as well as an expression of resentment of the price the public had exacted from her. In all honesty, the salt of the earth could be quite tasteless, and she was glad to dine, as it were, with ladies and gentlemen. When she returned to the English midlands in her next works her persona had gained a more assured, cosmopolitan perspective, as though she claimed the artistic equivalents of Romola's inherited advantages as well as the prerogatives that any English gentleman could take for granted. The strain of Romola paid off.

Similarly, Woolf had more to show for herself, to those who knew her from her works or in person, than Orlando's "The Oak Tree" and "'The Burdett Coutts' Memorial Prize" (312). ${ }^{28}$ The epic poem seems almost the natural offspring of tradition; certainly it is no experiment of high modernism, though for the implied author if not for Orlando it opens new generic territory. Orlando itself, of course, encompasses "The Oak Tree," synthesizing elements of the entire history of English literature as the poem could not. The author, whom we know as a child of literary criticism, raised among famous writers, must be amused by Orlando's dismay at the human failings of literati and the decline of patronage. Always in the vanguard as her protagonist brings up the rear, Woolf seems to recall with some indulgence her own development toward literary independence, from the early absorption of her father's library, through an apprenticeship in the nineteenth-century novel, to the new voices and forms from Jacob's Room onward.

This literary progress also enacts a shift in forms of heroism. It is as though the hero, like Jacob (whose name recalls the patriarchal thief of the birthright), had become the mock hero in Orlando, only to be supplanted, in a trance, by the true feminine heir. In The Waves six personae divide between them the "many different people . . . all having lodgment at one time or another in the human spirit" $(O$ 308). Thus the feminine heroism of renunciation that Eliot celebrates becomes the selflessness of the magnanimous creature who is all ages

\footnotetext{
${ }^{28}$ Sackville-West's "The Land" and the Hawthornden Prize are the patent parallels. Woolf, while she admired Sackville-West's talent, also said she had a "pen of brass" (Nicolson 3: $x x-x x i i)$ and viewed the Hawthornden award ceremony as a display of literary philistinism (VW Diary 3: 139).
} 
and sexes at once-with a twist of aristocratic egoism. The privilege of illimitable personality beyond gender was seized by this trickster in a book no one was to take seriously, so that the author's next experiments would be received as emanating from the grand old woman of English letters-with a playful difference.

Orlando has all the charm that Romola lacks. And yet we can see that the erudite historical romance and the belletristic jeu d'esprit alike devise a role for the great woman, reconciling romantic individuality and a collective tradition, rebellion and duty. While "the movement" of Eliot's "mind" may have been "too slow" for humor ("GE" [1919] 155), the escapade Woolf allowed herself in Orlando may have been too mercurial; the tendency to be pedantic or to be arch is part of each writer's response to an entire cultural history. Perhaps feeling that they had begun like Flush-awed, puzzled, bound by a leash to the masters or mistresses they loved-they had overcome the dutiful role of sightseer and had learned to trespass. At the same time, in each work the author raises a monument to the dominant cultural heritage; even the iconoclastic Orlando suggests that radical changes-of sex, perception, style-are mere intensifications of what went before. As Orlando says to the dead queen returning to the ancestral home in the moonlight, "Nothing has been changed. The dead Lord, my father, shall lead you in" (328). 